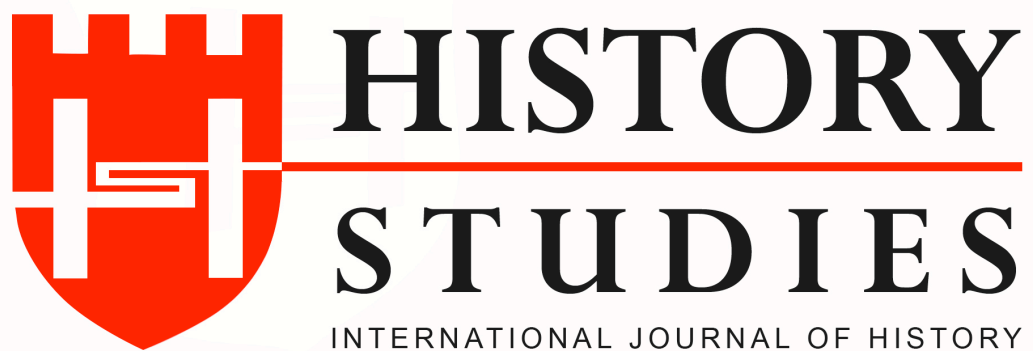

ISSN: 13094173 (Online) 1309 - 4688 (Print)

Volume 11 Issue 2, A tribute to Prof. Dr. Mehmet Ali ÜNAL, April 2019

DOI Number10.9737/hist.2019.738

Araștırma Makalesi

Makale Geliş Tarihi: 16.02.2019 - Kabul Tarihi: 25.03.2019

Atıf Künyesi: İlyas Topçu, “1950 Milletvekili Seçimleri Sonrası Cumhuriyet Halk Partisi’nden İlk İstifa ve

Demokrat Parti’ye Geçen Üç Vekil: Abbas Çetin, Latif Aküzüm, Veyis Koçulu”, History Studies, 11/2, Nisan 2019, s. 749-764.

\title{
1950 Milletvekili Seçimleri Sonrası Cumhuriyet Halk Partisi’nden İlk İstifa ve Demokrat Parti'ye Geçen Üç Vekil: Abbas Çetin, Latif Aküzüm, Veyis Koçulu
}

The First Resignations from The Republican People's Party After The 1950 Turkish General Election and The Three Mps Joining The Democratic Party: Abbas Çetin, \author{
Latif Aküzüm, Veyis Koçulu \\ Dr. İlyas TOPÇU \\ ORCID No: 0000-0002-9460-1127 \\ Kafkas Üniversitesi, İktisadi ve İdari Bilimler Fakültesi - Kars
}

\begin{abstract}
Öz: Türkiye Cumhuriyeti kurulduktan sonra iki defa çok partili hayata geçiş denemesi yapılsa da partilerin kısa bir süre sonra kapatılması sebebiyle 1950 yılına kadar Cumhuriyet Halk Partisi tek başına ülkeyi yönetmeye devam etti. İkinci Dünya Savaşı sonrasında oluşan konjonktüre paralel olarak Türkiye'de iç ve dış politikada önemli değişimler yaşandı. 7 Ocak 1946 tarihinde siyaset sahnesinde yerini alan Demokrat Parti, 1950 seçimleriyle beraber iktidara geldi ve 27 Mayls darbesine kadar da ülkeyi tek başına yönetti. On yıllık süre zarfinda yapılan üç genel seçimi de kazanan DP, ülke genelindeki başarısını Kars'ta gösteremedi ve Kars'tan milletvekili çıkarmayı başaramadı. Fakat 1950 seçimlerinde Kars'tan milletvekili seçilen üç kişi, Abbas Çetin, Veyis Koçulu ve Latif Aküzüm, 18 Mart 1952'de CHP'den istifa ederek DP saflarına geçtiler. Bu üç vekilin istifası yerel ve ulusal basında uzun bir süre gündemde kaldl ve basın üzerinden polemikler yaşand. İstifa eden ü̧̈ vekil, 1954 ve 1957 milletvekili seçimlerinde Kars'tan DP listesinde seçimlere girdiler fakat iki seçimde de meclise girmeyi başaramadılar. Bu çalışmada 1950 seçimleri ve milletvekillerinin istifaları, basındaki söz düellosu ve sonraki seçimler hakkında bilgi verilmeye çalışıldı.
\end{abstract}

Anahtar Kelimeler: DP, CHP, Seçimler, Kars, Basın.

Abstract: Although the twice multiparty transition attempts have been undertaken after the founding of Republic of Turkey, The Republican People's Party (CHP) had continued to rule the country on its own until 1950 because these parties were closed shortly thereafter. In parallel with the conjuncture formed after the Second World War, significant changes took place in Turkey's domestic and foreign policy. The Democratic Party (DP), which took its place on the political scene on January 7, 1946, came to power with the 1950 Turkish general election and had governed the country alone until the Military Coup of May 27, 1960. DP, which also won three general elections over a ten-year period, failed to show his countrywide success in Kars and couldn't have any deputy from Kars. But three deputies from Kars who were elected in the 1950 general election, Abbas Çetin, Veyis Koçulu and Latif Aküzüm, resigned from the CHP joined to the DP on March 1952. The resignation of these three deputies had remained on the agenda for a long time in the local and national press and there had been polemics via the press. The three resigned deputies became candidates of the DP in the 1954 and 1957 general elections, but they failed to get into the parliament in both elections. In this study, it was tried to give information about the 1950 election, resignations of these deputies, the wordy warfare in the press and the next elections.

Keywords: The Democratic Party (DP), The Republican People's Party (CHP), Elections, Kars, Press. 


\section{Giriş}

1945 yılından itibaren Türkiye'de iç politika gelişmeleri gözle görülür bir şekilde hızlandı. Halkın yıllardır süren tek parti idaresinden hoşnutsuzluğu II. Dünya Savaşı'nın ekonomik sıkıntılarıyla birleşince had safhaya ulaştı. Türkiye savaşa girmedi ama savaşın tüm sıkıntılarını yaşadı. Ekmeğin karneye bağlanması, şeker yerine üzüm ve incir gibi tatlandırıcılar kullanılması ve karaborsanın alıp yürümesi karşısında halk bütün bunların sorumlusu olarak Cumhuriyet Halk Partisi idaresini görmekteydi. 1945'lerde değişen dünya koşulları Türk toplumunda belirli bir hareketlilik yarattı. Türkiye'de giderek daha da gelişen ticaret ve tarım burjuvazisi, artık tek partinin yönetiminden kurtulmak istiyordu. Bu kesim savaş içerisinde elde ettiği ekonomik gücü siyasal iktidarla da birleştirmek istiyordu. Diğer taraftan, tek parti iktidarı süresince dini konularda alınan kararlar ve bazı uygulamalar nedeniyle şeriat taraftarları CHP'yi ilk firsatta devirmeye hazırdılar. Gayrimüslim azınlıklar ise 1942'de uygulanan Varlık Vergisi'nin acısını unutmamışlardı. Bütün bunlar birleşince artık değişiklik zaruri bir hal aldı. ${ }^{1}$

İkinci Dünya Savaşından sonra Türkiye'de dış politikayla ilgili de önemli gelişmeler görüldü. Savaşın ( hem Batı hem Sovyet) "demokrasi cephesinin" zaferiyle sonuçlanması Türkiye'de çoğulcu demokrasi yönünde gelişmelerin hızlanmasını sağladı. Türkiye'nin Sovyet istekleri karşısında Batı'nın (ABD’nin) desteğine olan ihtiyacı da Batı tipi siyasi sisteme geçişte önemli bir rol oynadı. Devlet Başkanı İnönü’nün bizzat yön verdiği gelişmeler sonucu 1945-46'dan itibaren Türkiye'de çok partili demokrasi yolunda hızlı adımlar atılmaya başladı. ${ }^{2}$

CHP'nin 17 Haziran 1945 milletvekili ara seçimlerinde aday göstermemesi, partinin çok partili siyasi hayat konusundaki bakışında çok katı olmadığını gösterdi. ${ }^{3}$ Bu süreçte teklif sahiplerinin yeni bir parti kurarak fikirlerini tartışmaya açmaları beklenirken 7 Temmuz 1945 tarihinde sanayici Nuri Demirağ Milli Kalkınma Partisini kurmak için İçişleri Bakanlığı'na başvurdu. ${ }^{4}$

Şükrü Saraçoğlu Hükümeti'nce hazırlanan Toprak Reformu tasarısı Ocak 1945'te Türkiye Büyük Millet Meclisi’ne sunulduğunda 7 Haziran 1945 tarihinde İzmir Milletvekili Celal Bayar, İçel Milletvekili Refik Koraltan, Kars Milletvekili Fuat Köprülü ve Aydın Milletvekili Adnan Menderes imzalarıla CHP Meclis Grubu'na verilen önerge, CHP Meclis Grubu'nun 12 Haziran günü yaptığı toplantıda okundu ve reddedildi. Önergenin reddinin gerekçesi ise, grup başkanlığının bildirisinde, müracaatın usul bakımından hatalı olduğu, kanun değişikliği için

\footnotetext{
${ }^{1}$ Filiz Çolak, "Türkiye'de Çok Partili Hayata Geçiş ve Demokrat Parti (1945-1950),” Türkler, Ankara, 2002, s. 774.

2 Ömer Kürkçüoğlu, "Dış Politika nedir? Türkiye'nin Dünü ve Bugünü," AÜSBF Dergisi, Cilt 35, Sayı:1, 1980, s. 322; "Çoğulcu, kapitalist bir demokrasi olan ABD savaştan egemen bir dünya gücü olarak çıktı ve onun örneği bütün dünya ülkelerinde olduğu gibi Türkiye'de de birçoklarını etkiledi. Nisan 1945'te Türkiye San Fransisko Konferansı'na kurucu üye olarak katılarak, Birleşmiş Milletler anlaşmasını imzaladı ve demokratik idealler için kesin söz vermiş oldu.” Erik Jan Zürcher, Modernleşen Türkiye'nin Tarihi, Çev: Yasemin S. Gönen, İletişim Yayınları, İstanbul, 1995, s. 302; 5 Haziran 1946'da 4919 sayılı yasa ile Türkiye'de parti kurmayı hükümetin iznine bağlayan Dernekler Yasasında değişiklik yapılarak yeniden serbestlik sistemine dönüldü "Cemiyetler Kanunun Bazı Maddelerinin Değiştirilmesine Dair Kanun,” Resmi Gazete, 10 Haziran 1946.

${ }^{3}$ Ercan Haytoğlu, "1945'te Çok Partili Siyasi Hayata Geçişte Bir İlk: Milli Kalkınma Partisi," Türkler, Ankara, 2002, s. 783.

${ }^{4}$ Olcay Ö. Duman-Haktan Birsel, "Demokrat Parti'nin Dış Politikası ve Bu Politikanın Dinamiklerine Etki Eden Dış Gelişmeler", Atatürk Üniversitesi, Atatürk Illkeleri ve İnkilap Tarihi Enstitüsü, Atatürk Dergisi, 2012, 301; "Nuri Demirağ'ın MKP'yi kurmak amacıyla yazdığı dilekçe, 9 Temmuz 1945 tarihinde İstanbul Valiliği'ne geldi ve gereken incelemenin yapılması için Hukuk İşleri Müdürlüğü'ne havale edildi. Cemiyetler Kanunu'nun 4. maddesine göre, cemiyet teşkili için verilen dilekçelere iki adet cemiyet ana nizamnamesinin eklenmesi gerekli olduğu ve Nuri Demiră̆' $1 n$ bu formaliteyi yerine getirmediği için talebi reddedildi. Parti nizamnamesinin bir süre sonra tamamlanması ile parti kurucularının isimleri bulunan dilekçe ve 87 maddelik ana nizamname vilayete verildi. Nizamnameye parti kurucuları olarak Nuri Demirağ, Hüseyin Avni Ulaş ve Cevat Rıfat Atilhan'ın isimleri yazılıydı." Haytoğlu, agm, s. 783 .
} 
Meclise, tüzük değişikliği için ise Kurultaya tekliflerin getirilmesi gerektiği şeklinde açıkland ${ }^{5}$. Takrire imza atan milletvekillerinden Adnan Menderes ile Fuat Köprülü Vatan Gazetesi'nde muhalif yazılar yazmaya başlamışlardı. İşledikleri tema, millet egemenliğinin sağlanması, insan hak ve hürriyetlerinin güvenceye alınması, anti-demokratik hükümlerin kaldırılması ve baskıya son verilmesidir. Menderes ve Köprülü'nün yayımlanan makaleleri, CHP yönetiminin takrircilerle ilgili somut bir tavır takınmasına zemin hazırladı. Partinin bilgisi dahilinde olmayan faaliyetlerin, doğrudan parti disiplinini zedeleyici olduğu gerekçesiyle, Menderes ve Köprülü Parti Disiplin Kurulu'na sevk edildi ve "Partinin iç durumunu bozmak için partide kaldıkları" gerekçesiyle 21 Eylül'de partiden ihraç edildiler. ${ }^{6}$ Ardından Celal Bayar, Büyük Millet Meclisi Başkanlığı'na kısa bir mektup göndererek 26 Eylül 1945 tarihinde İzmir milletvekilliğinden, ${ }^{7} 2$ Aralık 1945 'te de CHP'den istifa etti. ${ }^{8}$ Dörtlü Takriri imzalayan Refik Koraltan ise, Vatan Gazetesi'ne arkadaşlarının ihracının parti tüzüğüne aykırı olduğunu iddia edince 27 Kasım 1945 tarihinde partiden ihraç edildi. ${ }^{9}$

Milletvekilliğinden de istifa eden Bayar, 3 Aralık 1945'de yeni bir parti kuracağını açıkladı. Bu açıklamayı izleyen birkaç gün içerisinde Cumhurbaşkanı İsmet İnönü, Celal Bayar'ı Çankaya Köşkü'ne çağırdı ve birlikte yemek yediler. İki lider politikacı bu yemekte, savaş sonrası dünyada Türkiye'nin yalnız kalmaması için çok partili yaşama geçilmesinin kaçınılmaz olduğu fakat daha önceki olumsuz deneyimler nedeniyle bu konuda dikkatli olunması gerektiği konularında fikir alışverişi yaptılar. Ayrıca dış politika konusunda polemiklere girilmemesi, CHP iktidarının yeni kurulacak partiye engeller çıkarmaması da görüşülen konular arasındadır. Böylece İsmet İnönü, Türkiye açısından çok önemli sonuçlar vermesi beklenen demokrasi devresine kontrollü bir muhalefetle girmeyi planladığını göstermiş oluyordu. Bu görüşmenin ardından 7 Ocak 1946 tarihinde Bayar, Koraltan, Menderes, Köprülü’nün önderliğinde DP kuruldu. ${ }^{10}$

1946 genel seçimlerinden önce çıkartılan 4918 sayılı Milletvekilleri Seçim Kanunu ile iki dereceli seçim sistemi, tek dereceli seçim sistemine dönüştürüldü. ${ }^{11}$ Ancak "açık oy gizli tasnif" yöntemi kullanıldı ve denetim adli birimler yerine idari birimlerce yapıldı. Bu nedenle seçim sonuçları üzerinde uzun süren tartışmalar yaşandı. ${ }^{12} \mathrm{DP}$, kuruluşundan sonra girebileceği ilk mahalli idare seçimlerini mevzuatı anti demokratik bularak boykot etti ${ }^{13}$ ve iktidarı

\footnotetext{
${ }^{5}$ Süleyman İnan, Muhalefette Adnan Menderes (1945-1950), (Yayınlanmamış Doktora Tezi), Isparta, 2002, s. 80

${ }^{6}$ Selahaddin Bakan-Hakan Özdemir, "Türkiye'de 1946-1960 Dönemi İktidar-Muhalefet İlişkileri: Cumhuriyet Halk Partisi Demokrat Parti’ye Karş1,” CÜ, İktisadi ve İdari Bilimler Fakültesi Dergisi, Cilt 14, Sayı: 1, 2013, s. 377.

${ }^{7}$ Orhan Cemal Fersoy, Bir Devre Adını Veren Başbakan Adnan Menderes, İstanbul, Maytaş Matbaacılık, 1971, s. 103.

${ }^{8}$ Şevket Süreyya Aydemir, Menderes 'in Dramı, 14. Basım, İstanbul, Şubat 2013, s. 127.

${ }^{9}$ Mustafa Serhan Yücel, "Menderes Dönemi (1950-1960)," Türkler, 2002, Ankara 16. cilt s. s. 50.

10 Tevfik Çavdar, Türkiye'nin Demokrasi Tarihi 1839-1950, Ankara, 1995, s. 402; "Kurulduğu günden itibaren yoğun bir ilgi ve taleple karşı karşıya kalan DP, halk arasında "Demir Kırat" olarak adlandırılmıştır. "Demir Kırat" kısa sürede Türk siyasetinde "46 ruhu" olarak bilinen mücadelenin ve demokrasinin simgesi haline gelecektir." Sedef Bulut, "27 Mayıs 1960'dan Günümüze Paylaşılamayan Demokrat Parti Mirası,” SDÜ Fen Edebiyat Fakültesi, Sosyal Bilimler Dergisi, Mayıs 2009, Sayı 19, s.74; Aydemir, age, s. 127.

11 "İki dereceli seçim sisteminde, seçmenler önce delegeleri (bunlara ikinci seçmen ya da büyük seçmenler de deniyor) seçerler, bunlar da yeni bir seçimle milletvekillerini seçerlerdi. Tek dereceli seçim sistemi ise seçmenlerin temsilcilerini aracısız, doğrudan seçmesidir.” Bülent Özgül, Seçim ve Seçim Sistemleri, Türkiye'deki Seçim Sistemi Uygulamalarl ve Bir Model Önerisi, (Süleyman Demirel Üniversitesi, Yayımlanmamış Yüksek Lisans Tezi), Isparta, 2002, s. 45.

${ }_{12}$ DİGM, Milletvekilleri Genel Seçimleri 1923-2007, TÜİK Matbaası, Ankara, 2008, s. 12

13،"Belediye seçimleri bu tartışmalar arasında 26 Mayıs 1946 günü yapıldı. Demokrat Parti, resmî bir açıklamayla, partili ve taraftarı olan seçmenlerine sandığa gidip gitmemekte serbest bıraktı. Bu kararın alınmasında, İnönü’nün kurultaydaki sözleriyle, seçime katılmamakla vatan hainliğinin eşdeğer tutulacağı anlamını taşıyan uyarısı etkili oldu. Fakat Demokrat Parti gizliden bütün DP örgütlerine seçimlere katılmama çağrısı yaptı. Çünkü seçimlere
}

\section{History Studies}


meşruiyet sorunu ile baş başa bıraktı. 26 Mayıs 1946 tarihinde yapılan mahalli seçimlerde bunlar yaşanırken, 21 Temmuz 1946' da yapılan milletvekili genel seçimlerine CHP'nin dışında çok partili siyasal yaşamın ilk partisi olan ve 18 Temmuz 1945 tarihinde Nuri Demirağ tarafindan kurulan Milli Kalkınma Partisi (MKP) ile 7 Ocak 1946 tarihinde kurulan Demokrat Parti katıldı. ${ }^{14}$ Türkiye tarihinin ilk tek dereceli, açık oy, gizli tasnif ve basit çoğunluk ilkelerine göre yapılan seçimi 21 Temmuz 1946 tarihinde yapıldı. Tarihe "hileli seçimler" olarak geçen 1946 seçimlerini CHP kazansa da, DP'nin de ciddi bir başarı sağladığı söylenebilir. ${ }^{15}$

DP, 465 sandalye için 273 aday gösterdi ve bunlardan 66'sını Meclis'e sokmayı başardı. DP'nin örgütlenme firsatı bulamadığı için seçime katılmadığ1 16 il; Çorum, Kırşehir, Niğde, Malatya, Gümüşhane, Rize, Bingöl, Diyarbakır, Mardin, Siirt, Bitlis, Muş, Ağrı, Kars, Van ve Hakkari idi. Batı Anadolu şehirlerinde iyi sonuç alan DP'nin kazandığı 12 il: Edirne, İstanbul, Çanakkale, Muğla, Burdur, Afyon, Bilecik, Bolu, Kastamonu, Sinop, İçel ve Kayseri'ydi. CHP ise, kırsal kesim ile Karadeniz, Doğu, Orta ve Güneydoğu Anadolu'dan destek almıştı. DP'lilere atfen basında yer alan haberlerde, seçimlerin özellikle il merkezlerinde CHP'li hükümet bürokrasisinin baskısı altında yapıldığı, bazı bölgelerde seçim mazbatalarının değiştirildiği, bu yüzden toplu halde istifa edecekleri bile söyleniyordu. ${ }^{16}$

\section{14 Mayıs 1950 Milletvekili Seçimleri}

Gerginliklerle geçen dört yılın ardından 16 Şubat 1950 tarihinde seçim kanunu yeniden düzenlendi. Kanun görüşmeleri sırasında konuşan Adnan Menderes, bu kanunun demokratikleşme aşamasında önemli bir adım olduğunu söyledikten ve 1950 seçimlerinin önemi üzerinde durduktan sonra "memleket hesabına mesut başlangıçlardan biri olması temennisiyle partimiz Seçim Kanununu kabul etmektedir” diyerek olumlu oy kullanacaklarını açıkladı. Millet Partisi adına konuşan Hasan Dinçer ise, kanunu ana prensipleri itibariyle eksik bulduklarını ve bu nedenle desteklemeyeceklerini söyledi. ${ }^{17}$

DP ve CHP işbirliği ile çıkartılan bu seçim kanunu, tek dereceli, eşit ve gizli oy, açık tasnif ve her ilin bir seçim çevresi kabul edildiği "çok oy alanın seçilmesi" ilkelerine dayalı, yargının denetim ve yönetiminde bir seçim sistemi getirmekteydi. Yeni seçim kanunu, seçim sürecini yargının yanı sıra, seçmenin denetimine de açtı. Bu bağlamda, seçmen kütükleri halkın incelemesine açıldı, seçim hükümet işi olmaktan çıkarılıp halkın ve partilerin yürüteceği bir etkinlik olarak tanımlandı, seçimin yürütülmesi sırasında hükümet görevlilerinin kötü eylemleri seçim suçları arasına alındı ve seçim uygulamaları hakkında şikayet ve itiraz olanakları sağlandı. Seçim kanunu kabul edildikten bir ay sonra, seçimlerin yenilenmesi kararıla TBMM dağ 1 ld. ${ }^{18}$

katılma oranının düşük olması, Demokrat Partinin gücünü ortaya koyacaktır. Bunun yanında, DP seçimleri denetlemek için sandık başlarına gözlemciler gönderdi ve onlardan raporlar aldı. Ayrıca, vatandaşlar da şikâyetlerini DP merkezlerine bildirmeye davet edildiler. Demokrat Parti, seçimlere karşı böylece açık isteksizlik gösterdi. Diğer muhalif parti Milli Kalkınma Partisi ise, seçimlere 8 Mayıs'ta katılacağını açıklamışken seçim günü, yani 26 Mayıs'ta İstanbul'da yapılacak bir açıklamayla, hükümeti taraf tutmakla ve fesat karıştırmakla suçlayarak seçimlerden çekilmeye karar verdi.” İnan, agt, s. 124-125.

${ }_{14}^{14}$ DİGM, Milletvekilleri Genel Seçimleri 1923-2007, s. 12.

${ }^{15}$ Yücel, agm, s. 836.

${ }^{16}$ Hikmet Özdemir, "Demokrasiye Geçiş ve Menderes Dönemi," Türkler, Cilt 16, Yeni Türkiye Yayınları, Ankara, 2002, s. 882.

${ }^{17}$ TBMM Tutanak Dergisi, 16.02.1950, s. 706-709.

${ }^{18}$ Süleyman Güngör, "14 Mayıs 1950 Seçimleri ve CHP'de Bunalım,” SDÜ Fen Edebiyat Fakültesi Sosyal Bilimler Dergisi, Mayıs 2010, Say1 21, s. 194. 
Genel Seçimler, 14 Mayıs 1950 günü gerçekleşti. Cumhuriyet Halk Partisi bütün illerde, Demokrat Parti Hakkari hariç bütün illerde, Millet Partisi ise 22 ilde seçimlere katıldı. ${ }^{19} 14$ Mayıs 1950'de yapılan, Cumhuriyet tarihinin ilk tek dereceli, genel, gizli eşit oy, yarg1 denetiminde açık tasnif, basit çoğunluk kuralları ile yapılan seçimde Türk halkı Demokrat Parti'yi tartışmasız bir şekilde iktidara taşıdı. ${ }^{20}$ Toplam 8.905.743 kayıtlı seçmenin olduğu 14 Mayıs 1950 seçimlerinde 7.953 .085 seçmen oy kullanmak için sandık başına gitti. Katılım oranı \%89.3 olarak gerçekleşen 14 Mayıs seçimlerinde partilerin aldıkları oy ve çıkardıkları milletvekili sayıları tablo 1 'de gösterildiği gibidir. ${ }^{21}$

Tablo 1: 1950 Milletvekili Seçimleri Ülke Genelinde Seçim Sonuçları ${ }^{22}$

\begin{tabular}{|l|c|c|c|}
\hline \multirow{2}{*}{\multicolumn{1}{c|}{ Partiler }} & \multicolumn{3}{c|}{$\mathbf{1 9 5 0}$} \\
\cline { 2 - 4 } & Oy & Oran & $\mathbf{M . v k}^{\mathbf{2 3}}$ \\
\hline AP & - & - & - \\
\hline CHP & 3.176 .561 & 39,9 & 69 \\
\hline DP & 4.241 .393 & 53,3 & 416 \\
\hline MP & 250.414 & 3,1 & 1 \\
\hline Bağımsız & 383.282 & 4,8 & 1 \\
\hline
\end{tabular}

14 Mayıs 1950 milletvekili seçimleri yurtdışından da merakla izlendi. Türkiye'de görev yapan Sovyet, Çekoslavakya ve Polonya büyükelçileri çeşitli bölgeleri dolaşarak gözlem yaptı. ABD Dışişleri Bakanlığı'nca yapılan açıklamada seçimlerin "demokrasi için ibret alınacak bir zafer" olduğu belirtildi. New York Times gazetesi ise 27 yıllık tek parti iktidarını çürümüş bir rejim olarak tanımladı ve seçimlerle Türk halkının bu rejime karşı memnuniyetsizliğini dile getirdiğini yazdı. Daily Telepgraph gazetesi Türkiye'de uzun süredir bir istikrarsızlık olduğunu ve DP zaferi ile bu durumun sonlanacağını yazdı. Londra'da yayınlanan Daily Mail gazetesi ise seçimleri "hayret ve cesaret verici bir olay" olarak yorumladı. ${ }^{24}$

Menderes seçim sonuçlarını, Başbakan olarak hükümetinin programını okuduğu 29 Mayıs 1950 günü TBMM’de şöyle değerlendirecektir:

"Demokrat Partinin gayri tabiî siyasî şartlar içinde devam eden beş yıllık çetin mücadeleleri On Dört Mayıs seçimleriyle en muvaffakiyetli surette sona ermiş ve artık memleketimizde normal siyasi hayat başlamıştır. Şüphe yok ki, 14 Mayis, bir devre son veren ve yeni bir devir açan müstesna ehemmiyette tarihî bir gün olarak daima anılacaktır. Bu tarihî günün hatırasını yalnız partimizin değil, Türk demokrasisinin bir zafer günü olarak yâd ediyoruz." 25

\subsection{Kars'ta 1950 Milletvekili Seçimleri}

Kars'ta 1950 yılına kadar Cumhuriyet Halk Partisi bütün seçimlere tek başına girmişti. Demokrat Parti kurulduktan kısa bir süre sonra gerçekleşen 1946 seçimlerine teşkilatlanmasını tamamlayamadığı için giremediği illerden birisi de Kars'tı. Bu şartlar altında 1950 milletvekili seçimleri hazırlıkları yapılırken DP'nin Kars milletvekili adayları: Emin Akıncı (emekli

\footnotetext{
${ }^{19}$ Rifkı Salim Burçak, On Yılın Anıları (1950-1960), Ankara, Nurol Matbaacılık, 1998, s. 40.

${ }^{20}$ Rıdvan Akın, “Türkiye'de Çok Partili Siyasi Hayat Geçiş ve Demokrat Parti Yılları (1945-1960)," Türkler, 16. Cilt, Yeni Türkiye Yayınları, Ankara, 2002, s. 913.

${ }^{21}$ TÜiK, Milletvekili Genel Seçimleri 1923-2011, Yayın No: 3685, Ankara, 2012, s. 25.

${ }^{22}$ DİGM, 1950-65 Milletvekili ve 1961-64 Cumhuriyet Senatosu Üye Seçim Sonuçları, No: 513, Ankara, 1966, s. 7.

${ }^{23}$ TÜIK, age, s. 9.

${ }^{24}$ Muharrem Turp, “Türkiye'nin Demokratikleşme Sürecinde Bir Mihenk Taşı: Basında 1950 Seçimleri,” Çağdaş Türkiye Tarihi Araştırmaları Dergisi, 18/37, 2018, s. 693.

${ }^{25}$ TBMM, Tutanak Dergisi, 29.05.1950, s. 24-25.
} 
kurmay albay), İsmail Alaca (avukat), Zeki Aras (tüccar), Turgut Babaoğlu (serbest hekim), Fazıl Baykal(çiftçi), Nevruz Gündoğdu (çiftçi-tüccar), Ahmet Kağan (doktor), Kemal Tuğcu (doktor), Ali Topçu (yüksek orman mühendisi), ve Fahri Yemen'dir. Müstakil adaylar ise, Ali Ataman, Neşet Akmanlar, İbrahim Altıer, Mehmet Budak, Ali Erdem, Mustafa Tombul'dan oluşuyordu.

Aynı seçimler için Kars'ta CHP tarafından aday gösterilen 10 kişinin bulunduğu liste şu şekildedir: Fevzi Aktaş (8. Dönem milletvekili), Latif Aküzüm (avukat), Sırrı Atalay (yargıç), Mehmet Bahadır (8. Dönem milletvekili), Abbas Çetin (avukat), Veyis Koçulu (tüccar), Esat Oktay (8. Dönem milletvekili), Tezer Taşkıran (8. Dönem milletvekili), Hüsamettin Tugaç (8. Dönem milletvekili), Hüseyin Cahit Yalçın (8. Dönem milletvekili). ${ }^{26}$

14 Mayıs 1950 seçimlerinde Kars'ta toplam seçmen sayısı 156.502'dir. Bunların içerisinde oyunu kullananların sayısı ise 139.749 'dur. ${ }^{27} 14$ Mayıs 1950 genel seçimlerinde Kars'ta CHP, Demokrat Parti'den 22.449 oy fazla alarak tam liste halinde seçimleri kazandı. Bu suretle 10. Dönem TBMM'de Kars'1 temsil edecek olan 10 milletvekilinin tamamı CHP'dendi. Yeni teşekkül etmiş olan MP, Kars'ta son derece azınlıkta kaldı. ${ }^{28}$ Kars İl Seçim Kurulu tarafından Başbakanlık Yüksek Makamına gönderilen 05.19.1950 tarihli yazıda 5545 sayılı milletvekili seçimi kanununun 117. Maddesi gereğince Kars ilinden milletvekili seçilen 10 kişiye ait liste şu şekildedir: Fevzi Aktaş, Latif Aküzüm, Sırrı Atalay, Mehmet Bahadır, Abbas Çetin, Veyis Koçulu, Esat Oktay, Tezer Taşkıran, Hüsamettin Tuğaç ve Hüseyin Cahit Yalçın'dır. ${ }^{29}$

Kars'ta seçimlerin Demokrat Parti aleyhine sonuçlanmasında en önemli etkenlerden biri, il teşkilatının yeni kurulmuş olmasıdır. Seçim sürecine yaklaşılırken henüz ilçelerde teşkilatlanma fırsatı bulamayan ve seçmene ulaşamayan DP'nin, il ve ilçe merkezlerinde iyi organize olmuş CHP karşısında başarılı olması ihtimali zaten çok zayıftı. Ayrıca dönemin yerel gazeteleri incelendiğinde, henüz yeni kurulmuş olan DP ile ilgili sağlıklı bilgilere ulaşılamamaktadır. Buradan hareketle 14 Mayıs seçimleri öncesinde ve sonrasında yerel basının desteğini arkasına alamadığını belirtmek gerekir. DP'nin il ve ilçe kongreleri ile ilgili haberlerin gazetelerde ayrıntılı olarak 1952 yılından itibaren aktarılmaya başlandığ 1 görülmektedir. Bu haberlerde de çoğunlukla parti kongrelerinde yaşanan problemler ve hizipleşme önemli yer tutmaktadır. Şöyle ki, 23 Mayıs 1952 tarihinde yapılan DP il kongresinde yaşanan gerginlik ve problemler nedeniyle genel merkezden konuyu incelemek üzere müfettiş gönderildiği görülmektedir. Erzurum Milletvekili Mustafa Zeren ve Rıfkı Salim Burçak tarafından yapılan incelemeler neticesinde il idare kurulu görevden alındı ve yerine geçici olmak kaydıyla Zeki Aras başkanlığındaki heyet görevlendirildi. ${ }^{30}$

\section{Vekillerin CHP'den İstifaları ve Basındaki Yansımaları}

1946 yılında yapılan genel seçimlerle Türk siyaset sahnesinde yerini alan Demokrat Parti, 1946 seçimlerinde meclise girmeye hak kazanmış olsa da 14 yıl boyunca yapılan 4 genel seçimde Kars'tan milletvekili çıkarmayı başaramadı. 1950-1960 yılları arasında ülke genelinde büyük başarı sağlayan DP Kars'ta bir türlü umduğunu bulamadı ve CHP'ye Kars'ta galip gelemedi. ${ }^{31}$ CHP'li idare kurulu ile aralarındaki anlaşmazlık sebebiyle Kars milletvekillerinden

\footnotetext{
26 “CHP Tarafindan Gösterilen Adaylar,” Kars Gazetesi, 26 Nisan 1950.

${ }^{27}$ DİGM, 1951 İstatistik Yıllı̆̆l, Yayın No: 332, Ankara, 1951, s. 225.

28 "Seçimler Tamamen Vukuatsız Geçmiştir," Kars Gazetesi, 3 Mayıs 1954.

${ }^{29}$ Başbakanlık Cumhuriyet Arşivi, 030.10.77.511.11.

30 "Yetkili Parti Müfettişleri İl İdare Kuruluna Kifayetsizlikten Dolayı İşten El Çektirdi," Kars Gazetesi, 19 Ağustos 1952.

${ }^{31}$ Kaybedilen 1950 seçimlerinden hemen sonra Kars'1 kazanmak için DP'liler şehre sürekli ziyaretlerde bulundular. 1952'de Cumhurbaşkanı Celal Bayar'ın kalabalık bir heyetle yaptığı ziyaret olumlu etkiler yaratsa da seçim
} 
bazıları arasında ortaya çıkan fikir ayrılığı sonucunda CHP Kars Milletvekillerinden Latif Aküzüm, Abbas Çetin ve Veyis Koçulu CHP'den istifa ederek 18.03.1952 tarihinde DP'ye geçtiler. $^{32} 1950$ genel seçimlerinden sonra CHP'den istifa edip DP'ye geçen bu 3 milletvekilinin dışında DP Kars'tan 10 yıl boyunca milletvekili çıkaramadı.

$\mathrm{Bu}$ istifalar yerel ve ulusal basında önemli bir gündem haline geldi. Akşam gazetesinin ilk sayfasından verdiği haberde, bu istifaların CHP mahfillerince beklenen bir hadise olduğu aktarılıyordu. Gazeteye göre, CHP Genel Sekreterinin iştiraki ile Kars'ta yapılan CHP kongresinde kendilerini desteklemeyen bir idare kurulunun iş başına getirilmesi ve genel sekreterin bu duruma müdahale etmemesi sebebiyle bu üç vekilin partiden istifa ettikleri belirtiliyordu. Ayrıca istifa ettikleri günün akşamında DP Bahçelievler ocağına kayıt yaptırdıkları bilgisi de yer alıyordu. ${ }^{33}$ Milliyet gazetesi de ilk sayfadan "üç Kars milletvekili CHP'den istifa etti” başlığıyla haberi yayınladı. Haberde DP'ye geçen vekillerin istifa gerekçelerini mektupla açıkladıkları belirtiliyordu. ${ }^{34}$

Abbas Çetin, Veyis Koçulu ve Latif Aküzüm'ün CHP'den istifalarını Zafer Gazetesi okurlarına: "Halk Partisi'nde yeni çöküntüler" manşetiyle ilk sayfadan duyurdu. Haberde, şef sistemine ve jurnalciliğe tahammül edemeyen üç Kars milletvekilinin Halk Partisinden istifa ederek DP'ye kayıtlarını yaptırdıklarını; Halk Partisi içerisinde şeflik sisteminin devam etmesine ve jurnalcilerin hala insanları fişlemesine tahammül edemeyen Kars milletvekillerinin istifanamelerinin bir suretini Halk Partisine, bir suretini de TBMM başkanlığına verdiklerini belirtiliyordu. Ayrıca, Halk Partisi içinde nasıl hala gizli dolaplar çevrildiği ve şef sistemin nasıl devam ettiğinin anlaşılması için istifa eden milletvekillerinin istifanamelerinin tam metnini yayınladıklarını belirtiyorlard. ${ }^{35}$ İstifa metninde yer alan bazı hususlar sonraki günlerde partililer arasında basın üzerinden tartışma konusu oldu. Zafer Gazetesinin tam metin olarak yayınladığı ve tartışmalara sebep olan istifa metninin ilk kısmında:

“...Her şeyden evvel açıç̧a ifade etmeye mecburuz ki, Halk Partisi içersinde şeflik sistemi eskisi gibi devam etmektedir. Parti başkanının fikirlerine uygun fikirler beslemeyen partililer şüphe ile karşılanmaktadır...1950 tarihine kadar Kars'ta muayyen bazı eşhas Halk Partisi teşkilatına hekim mevkileri ellerinde tutarak ve bu mevkilerin nüfuzunu kullanarak memleket sekenesini fişlemek ve sürdürmek suretiyle sindirmiş ve vatandaşlar arasına çeşitli tefrikalar sokmuş bulunmaktaydı. Bütün memleket halkıyla beraber bizler de bu parçalayıcı ve ezici hareketin mevzii, şahsi menfaat ve ihtirastan kaynaklandığını zannetmekteydik. 1950'den itibaren Kars'ta ve Ankara'da vaki müracaatlar 30 y1ldan beri Kars'ta hüküm süren zihniyetin parti merkezince de benimsenmekte olduğunu izdırap ile müşahede etmiş bulunmaktayız." ${ }^{36}$

Yukarıdaki gibi başlayan istifanamede madde madde bazı hususlara temas edilmekteydi. Birinci maddede, 1950 seçimlerinde parti müfettişinin de bulunduğu milletvekili aday

sonuçlarını DP lehine değiştirmedi ve 1954 seçimleri CHP'nin zaferiyle sonuçlandı. 1954 seçimlerinden sonra şehre yapılan ziyaretler artmakla beraber, 1957 seçimlerinden hemen önce Başbakan Adnan Menderes de Kars'a geldi. Partinin il teşkilatı içerisinde yaşanan hizipleșmenin zirveye ulaştı̆̆ 1 bu yıllarda, Menderes'in ziyareti de Kars'ta DP'nin mağlubiyetini engelleyemedi. DP Türkiye siyaset sahnesindeki son milletvekili seçiminde de Kars'tan milletvekili çıkarmayı başaramadı. İlyas Topçu- Nebahat Oran Arslan, "Kars'ta 1950-1954-1957 Milletvekili Seçimleri ve Demokrat Parti”, Türkiyat Araştırmaları Enstitüsü Dergisi, Sayı: 58, 2017, s. 404.

32 “L. Aküzüm, A. Çetin ve V. Koçulu CHP'den DP'ye Geçtiler," Kars Gazetesi, 19 Mart 1952.

33 “Üç Kars Milletvekili CHP'den İstifa İle DP'ye Geçtiler," Akşam Gazetesi, 19 Mart 1952, s. 1-2.

34 “Üç Kars Milletvekili CHP'den İstifa Etti” Milliyet Gazetesi, 19 Mart 1952.

35 "Halk Partisinde Yeni Çöküntüler," Zafer Gazetesi, 19 Mart 1952.

36 “Halk Partisi Çöküyor,” Zafer Gazetesi, 19 Mart 1952, s. 5.

\section{History Studies}


belirleme seçimlerinde kendilerinin kazanmış olmasına rağmen, genel merkeze "komünistler kazandı" şeklinde telgraflar çekildiğini ve genel merkezin seçim neticesini bir hayli zaman sonra onayladığını, ayrıca, 1950 seçim çalışmalarında parti teşkilatında görev almış ve adaylık seçimini kazanamamış şahıslarında kendilerinin aleyhine çalıştıklarını iddia ediyorlardı. İkinci, üçüncü ve dördüncü maddelerde il parti teşkilatı içerisinde partiyle alakası olmayan kötü zihniyetli kişiler ile ilgili raporlar vermiş olmalarına rağmen, parti genel idare kurulu ve yetkili organlarının hiçbir reaksiyon göstermediği, bu şahısların partide çalışmaya devam ettikleri ve hatta ihya edildikleri iddia edilmekteydi. Son kısımda ise:

“...memleketimize imar bakımından çivi çakılmadığı gibi zengin topraklarımızın tabii servetinden de istifade sağlamak imkanları ihdas edilmemiştir...Kars bu güne kadar ihmal edilmiştir. Her türlü zümre ayrılığının farkında dahi olmayarak omuz omuza milli mücadelesini yapmış bulunan halk arasına yok yere çeşitli zümrecilik fikirleri sokulmuş ve teneffüs edilemez ağır bir hava yaratılmıştır. Bu havanın içerisinde fişlenmek, sürülmek ve milli emniyet teşkilatının takibine uğratılmak eksik kalmamıştır. Buna rağmen sırf Halk Partisi listesinde milletvekili seçilmiş olmak dolayısıyla Halk Partisi'nde samimiyet ve ciddiyetle çalıştık. Fakat bu bünye bizi bir türlü benimsemedi... 1zdıraplarımıza sessiz kaldı.

$\mathrm{Bu}$ itibarla, iki seneden beraber çalıştığımız gurup arkadaşlarımızdan memleket davalarını realist bir görüşle ele alan arkadaşlarımıza kalbi muhabbetimiz ve şahsi hürmetlerimiz baki kalmak kaydıyla, Halk Partisi'nden istifa ettiğimizi beyan ederiz" diyerek bitiriyorlard $1{ }^{37}$

Kars'ta 1952 yılında çıkan tek yerel gazete olan Kars Gazetesi'nde istifalar 19 Mart tarihli sayısının ilk sayfasında manşetten verildi. CHP kanadından: "çekilmeleri parti içerisindeki tesanütsüzlüğün izole edilmesine yardım edecektir. Bu sebeple tahmin ettiğimiz neticenin ortaya çıkması bizi şaşırtmadı" açıklamasının yapıldığı aktarılırken, DP kanadından ise: "bu şahısların Demokrat Parti'ye geçeceğini biz zaten biliyorduk" açıklaması yapıldı̆̆ aktarılıyordu. Haberin devamında; CHP il idare kurulunun çalışmalarından memnun olmadıklarını ileri süren milletvekillerinden Latif Aküzüm ve Abbas Çetin'in CHP'den istifa edeceklerini daha önceki seyahatlerinde seçmenler anlattıkları belirtiliyordu. Bu süreçte Abbas Çetin'in hükümet sözcüsü gibi açıklamalar yaptığı ve bunun da CHP mahfillerinde hoş karşılanmadığı aktarılıyordu. Nihayetinde bu vekillerin Ankara'ya gidişlerinin hemen ertesi gün DP Kars il başkanlığına telgraf çekerek: “18.03.1952 CHP'den istifa ettik, DP'ye geçtik. Hepinizi sevgilerimizle selamllyoruz" yazılı telgraf gönderdiler. ${ }^{38}$

Gazetenin sonraki günlerde de bu istifalarla ilgili haber yapmaya devam ettiği görülmektedir. 24 Marttan itibaren Zafer, Ulus, Kudret ve Vakit gazetelerinin konuyla ilgili yaptığı haber ve çıkan yazılar ayrı ayrı neşrediliyordu. ${ }^{39}$ Ayrıca Kars'ta söz konusu istifalar ile ilgili vatandaşlara sorulan sorular ve cevaplar da ilerleyen günkü gazetelerde ilk sayfadan aktariliyordu. ${ }^{40}$

İstifa eden milletvekillerinin Zafer Gazetesinde yayınlanan istifa mektuplarıla ilgili, CHP Genel İdare Kurulu üyelerinden Kemali Bayezit ve Kars milletvekili Sirrı Atalay Ulus Gazetesi'ne demeç verdiler. Atalay demecinde:

\footnotetext{
37 "Halk Partisi Çöküyor," Zafer Gazetesi, 19 Mart 1952, s. 5.

38 “L. Aküzüm, A. Çetin ve V. Koçulu CHP'den DP'ye Geçtiler,” Kars Gazetesi, 19 Mart 1952.

39 “Üç Vekilimizin İstifaları, Türk Matbuatı Ne Diyor,” Kars Gazetesi, 24 Mart 1952.

40 "Üç Vekilimizin İstifaları Hakkında Hemşerilerimizin Anketimize Verdikleri Cevaplar,” Kars Gazetesi, 25-26-2728-29 Mart 1952.
} 
“Kars milletvekillerinden üçü dün itibariyle CHP'nin şerefli sinesinden ayrıldılar. Talihleri ve yolları açı olsun. Şayet dünkü Zafer Gazetesinde insanı iğrendiren yazıları çıkmasaydı bu konu üzerinde durmayacaktık. CHP'yi arkadan hançerlediklerini, DP kurucularına yarandıklarını zannettikleri bu şerefli jestlerine gülüp geçecektik. Zira bu hareketlerini bekliyorduk. Bir sürpriz karşısında değiliz. Bu zihniyetin ve çekilmede gösterilen gülünçlügün karşısında hayretteyiz. Hiç olmazsa çekilme sebeplerinde biraz mertlik ve mantık gösterebilselerdi. CHP'de şeflik zihniyetinin devam ettiğini iddia edenler daha düne kadar büyük İnönü'nün yanında resimde görülmek için cehd-ü gayret sarf edenler, asla mecbur olmadıkları halde el öpmeye can atanlardır. Onlar ki CHP saflarına kırmızı mumla çağrılmadan girmiş kimselerdir" diyordu. ${ }^{41}$

Atalay demecinin devamında, CHP'nin Kars'ta yaptığı bazı işler ve imarlar karşısında üç vekilin nankörlük ettiklerini, Kars halkının bu şekilde partiden ayrılışlarını asla unutmayacaklarını söyledi. Yine Kars halkına seslenerek: "Zafer Gazetesinin velvele ve yalanlarına kapılmayınız. CHP'nin sinesinde ve Kars teşkilatında hiçbir çöküntü yoktur, CHP'nin Kars teşkilat kalesinden birkaç faydasız çakul koptu ve burçlar sağlamdır" diyordu. ${ }^{42}$

Sırrı Atalay'ın Ulus Gazetesinde yayınlanan demecine cevap gecikmedi ve istifa eden üç milletvekili Zafer Gazetesine açıklamalarda bulundular. Milletvekillerinin cevapları 21 Mart tarihli Milliyet Gazetesinde de ilk sayfadan verildi. ${ }^{43}$ Atalay'ın kırmızı mumla çağrılmadan CHP saflarına geçtiklerine dair ifadesine cevap olarak:

“Bizim CHP'ye kırmızı mumla çağrılmadı̆̆ımız muhakkaktır. Yıllardan beri şahsi menfaat bağlarıyla birbirlerine bağlanmış ve kristalize olmuş bu bünye hür fikirli kimseleri kabul etmemekte hüner sahibidir. Biz CHP'ye mücadele ile girdik ve girdiğimiz günden itibaren de zihniyet mücadelesi yaptık" şeklinde cevap verdiler. ${ }^{44}$

Atalay'ın sıhhatinin bu kadar yazıyı yazamaya müsait olmadığını, üslubundan da başkaları tarafından kaleme alındığ 1 açık olan bir yazıyı hatta tamamını okumamış olduğu da düşünülebilen bir yazının onun malıymış gibi neşrine rıza göstermesini hayret ve nefretle karşıladık diyorlardı. CHP'nin Kars'ta yaptığı bazı şeylere nankörlük ettikleri iddiasına da:

“Soruyoruz: 'bazı' kelimesinin muhtevası nedir? Hangi imar işleri yapılmıştır? Tren Kars hududunda kalmamış mıdır? Şehirlerarası telefon Erzurum'da durmamış mıdır? Tayyare seferlerinin son durağı Erzurum değil midir? İstirdattan evvel kırılıp yolların kenarına yığın yapılmış taşlar yerlerinde durmakta iken bütün il yolları birer bataklık haline gelmemiş midir? Dünyanın en zengin vadisi olan Aras Vadisinde her türlü sebze ve meyve yetişmekte iken Malatya'nın Adana'nın meyve ve sebzeleri Kars pazarına getirilebildiği halde, il dahilinde seyrüsefer imkansızlığı yüzünden vadinin servetleri çürümüyor mu...? $\mathrm{Bu}$ hakikatleri ifade etmek mi nankörlüktür, yoksa muhtevası olmayan 'bazı' kelimesiyle perdelemek mi? Takdir uyanık olduklarından şüphe edilmeyen hemşerilerimizindir... Mecliste 'Kars'a çivi çakılmamıştır' şeklinde söylediğimiz söz hakikatin kendisidir. Bu sözün Ulus Gazetesinde çıkmamış olması bizim namertliğimizden değildir. Ulus Gazetesinin ve onu idare eden

\footnotetext{
41،"Milletvekillerimiz Arasında Düello," Kars Gazetesi, 27 Mart 1952.

42 “Milletvekillerimiz Arasında Düello,” Kars Gazetesi, 28 Mart 1952.

43 “CHP'den İstifa Eden Üç Kars Milletvekili Dün İthamlara Cevap Verdiler," Milliyet Gazetesi, 21 Mart 1952.

44 “CHP'deki Bozgunun Sebepleri,” Zafer Gazetesi, 21 Mart 1952, s. 5.
} 
zihniyetin hakikatleri perdelemek gayretinden ve meclis zabtını tahrif ederek neşretmemesindendir" şeklinde cevap verdikleri görülmektedir. ${ }^{45}$

CHP Genel İdare Kurulu üyelerinden Kemali Bayezit'la ilgili olarak Vekiller, kendilerinin partiden ayrılışını sürpriz olarak değerlendirmeyenlerin kendilerini benimsememiş oldukları yönündeki iddialarının kanıtı olduğunu belirterek, söz ile yazı ile CHP'nin bir tüzük partisi olduğunu, şef sisteminin olmadığını ifade etmenin beyhude olduğunu beyan ettiler:

"Genel merkezin bizlere verdiği vazifeleri, vazifenin hususiyet ve ehemmiyetiyle mütenasip bir şekilde ifa etmişizdir. Ancak; Kemali Bayezit ve onun gibi yalnız kafaları değil bütün hücreleri dahi tek parti ve şef sisteminin itiyatlarıyla dolmuş, kendilerini iktidardan uzaklaştıran sisteme ve şahıslara değil, vatandaşları, dostları kardeşleri dahi olsa düşman nazarıyla bakmaktan kendilerini alamayanlar bizim şahsi dost ve arkadaşlarımızla parti ayrılığına rağmen insani münasebetlerimizi bir türlü hazmedememişlerdir" şeklinde cevap verdiler. ${ }^{46}$

14 Mayıs seçimlerinde CHP müfettişi olarak Kars'ta görev yapan Avukat Atalay Akan'da 28 Martta Kars Gazetesine mektup göndererek bu polemiğe katıldı. 29 Martta yayınlanan mektubunda üç vekilin Zafer Gazetesinde yayınlanan yazılarında kendisi ile alakalı cümlelere cevap vermek için gazeteye mektup yazdığını söyledi. Akan;

“1950 seçimlerinde Kars’ta parti müfettişi olarak bulundum. Benim Kars'a bazı notları hamilen götürdüğüm ve bu gün milletvekili bulunanları benimsemediğim yolundaki beyan tamamen yalandır. Benim parti merkezinden aldığım direktif, tüzük hükümlerini yerine getirerek yoklamayı yapmaktı. Bana parti merkezinden bir kimsenin yoklamada kazandırılması veya kazandırılmaması için hiçbir emir veya direktif verilmemiştir".

İstifalara de değinen Akan, şaşırmadığını ve hatta CHP Kars teşkilatında yapılması lazım gelen bir temizlik operasyonunun kendiliğinden yapılmış olduğunu, bu istifalar sayesinde CHP Kars teşkilatının daha rahat ve daha verimli çalışma imkanını elde ettiğini belirtiyordu. ${ }^{47}$

Yine Ulus Gazetesinde konuyla ilgili yazı kaleme alan Cemil Sait Barlas, CHP'den istifa eden milletvekillerinin samimiyetsizlikle suçlayarak, eğer samimi olsalardı asıl şef partisi olan DP'ye geçmezlerdi diyordu. Barlas: “kendi görüşlerine uymayan milletvekillerine dağa çık! diyen ve partisinden atan bir genel başkana sahip DP şef partisi değil de CHP mi şef partisidir" dedi. ${ }^{48}$

Mart ayının sonlarına kadar basının gündeminde kalan istifa ve polemiklerin, Nisan ayından itibaren gündemden düştüğü görülmektedir. İstifa eden vekiller DP saflarında siyaset yapmaya devam ederken, 1954 seçimleri için çalışmalara da yavaş yavaş başlandı.

\section{1954 ve 1957 Milletvekili Seçimlerinde İstifa Eden Vekillerin Durumu}

5545 sayılı Milletvekilleri Seçim Kanunu, üzerinde değişiklikler yapılarak 1954 ve 1957 seçimlerinde de kullanıldı. 40.000 nüfusu 1 milletvekilinin temsil edeceği ilkesi ile 22 olan seçmen yaşı da bu kanunda aynen yer aldı. Mevcut seçim yasasına göre, illerin çıaracağ 1 milletvekilleri sayıları, 40.000 nüfusa 1 milletvekili düşecek şekilde hesaplandığında, nüfus artışına paralel olarak milletvekilleri sayıları 1950'de 487 iken, 1957'de 610'a yükseldi. 1946-

\footnotetext{
45 "CHP'deki Bozgunun Sebepleri," Zafer Gazetesi, 21 Mart 1952, s. 5.

46 “CHP'deki Bozgunun Sebepleri," Zafer Gazetesi, 21 Mart 1952, s. 5.

47 "Milletvekillerimiz Arasında Yazı Düellosu Devam Ediyor," Kars Gazetesi, 29 Mart 1952.

48 “Milletvekillerimiz Arasında Yazı Düellosu Devam Ediyor," Kars Gazetesi, 30 Mart 1952.
}

\section{(}


1957 yılları arasında yapılan seçimlerde, tek dereceli liste usulü çoğunluk seçim sistemi uygulandı. Bu sisteme göre, kullanılan oyların salt çoğunluğunu alan parti, o seçim bölgesindeki tüm milletvekillerini kazanıyordu. ${ }^{49}$ Ülke genelinde 1954 seçimlerine CHP ve DP'den başka CMP ve KP'de katıld..$^{50}$

2 Mayıs 1954 günü yapılan genel seçimlerden Demokrat Parti, Cumhuriyet tarihinin rekor oranıyla galip çıktı: \%56.6 oy alan Demokrat Parti, 503 milletvekilliği kazandı. CHP ise \%34.8 oranla parlamentoya ancak 31 milletvekili sokabildi. Yürürlükte olan çoğunluk sistemi DP'ye milletvekilliklerinin neredeyse tamamını kazandırdı: \%56.6 oy karşılığında milletvekilliklerinin \%93'ünü aldı. ${ }^{51} \%$ 4,8 oy alan CMP ise 5 milletvekili, \%1,5 oy alan bağımsızlar ise 2 milletvekili çıkardılar. ${ }^{52}$ Kars'ta CHP 79.426, DP 61.573 ve CMP ise 18.400 oy aldı. ${ }^{53} 1950$ milletvekili seçimlerinde CHP listesinden aday olup, milletvekili seçilen ve daha sonra da CHP'den istifa ederek DP'ye geçen 9. Dönem Kars milletvekilleri Abbas Çetin, Latif Aküzüm ve Veyis Koçulu bu seçimlerde DP listesinden aday oldular. Partilerinin Kars ve ilçelerinde yaptıkları mitinglerde de aktif bir şekilde çalışmalarda bulunan üç vekil mevcut seçim sisteminin de etkisiyle meclise girmeyi başaramadılar. ${ }^{54}$

Demokrat Parti'nin iktidarda olduğu dönemde yapılan son milletvekili seçimleri 27 Ekim 1957 tarihinde yapıldı. Seçimlere katılım oranı \%76.6 seviyesinde gerçekleşti. Demokrat Parti oylarını yüzde ellinin altına düşürdü ve \%47.3'te kaldı. Cumhuriyet Halk Partisi ise \%40.6 oranını yakaladı. Çoğunluk sistemi yürürlükte olduğundan, oy oranlarına göre milletvekili sayılarındaki adaletsizlik bu seçimlerde de göze çarpıyordu; DP 424 milletvekili, CHP 178 milletvekili kazand1. ${ }^{55}$ DP bu seçimlerde ilk kez seçmen düzeyinde çoğunluğunu kaybetti, DP'nin yüzde 48'lik oyunu sadece altı puan geriden CHP izliyordu. Genelde muhalefetin, özelde CHP'nin kendisine özgüveni çok artmıştı. Eğer seçimlerde basit çoğunluk sistemi değil nispi temsil sistemi uygulansa idi, DP bu seçimi kaybedebilir, karşısındaki muhalefet bloğu bir koalisyon hükümeti oluşturabilirdi. DP seçim sistemini basit çoğunluktan nispi temsile çevirme önerilerini sürekli reddetti. Önde gelen bir DP'li, Rıfkı Salim Burçak, Zafer'de yayınladığı makalesinde "Nispi temsil sistemi bizim memleketimizin bünyesine katiyen uygun değildir" yargısında bulunacaktı. Bu seçimlerde tek listeli basit çoğunluk sistemi oyların \%48'ini alan iktidar partisinin TBMM'deki sandalye sayısının \%75'ini elde etmesine, buna karş11ı \%52 oy alan muhalefet partilerinin \%30'da kalmasına da yol açacaktı. ${ }^{56}$

1957 genel seçimleri için DP’nin aday listesinde, İsmail Alaca, İsa Taşdemir, Mecit Gezer, Celal Nuri Koç, Alaaddin Metan, Haşim Dursunoğlu, Zeki Aras, Rüştü Öktem ve Zarif Akman'dan başka 18 Mart 1952'de CHP'den ayrılan üç vekil Abbas Çetin, Latif Aküzüm, Veyis Koçulu da vard1. ${ }^{57}$

\footnotetext{
${ }^{49}$ DİGM, Milletvekilleri Genel Seçimleri 1923-2007, 2008, s. 12.

${ }^{50}$ TÜIK, age, s. 4.

${ }^{51}$ Yücel, agm, s. 838.

52 Fatma Alev Ataykul, Türkiye'de Demokrat Parti Döneminde Genel Seçimler (1950-1954-1957), (Yayınlanmamış Yüksek Lisans Tezi), İstanbul, 2007, s. 310.

${ }^{53}$ DIGM, age, s. 28-29.

542 Mayıs 1954 seçimlerinde Kars milletvekili olmaya hak kazanan şahıslar ve toplam sayısı 177.954 olan seçmenden aldıkları oy miktarı şu şekildedir: Kemal Güven 79.410 oy, İbrahim Us 75.980 oy, Sırrı Atalay 85.470 oy, Remzi Çakır 77.358 oy, Mehmet Hazer 79.236 oy, Turgut Göle 83.948, Hasan Erdoğan 79.623, Ali Yeniaras 77.250, Fevzi Aktaş 77.995 ve Rıza Yalçın 77.369 oydur. BCA, 030.10.78.517.15.

${ }^{55}$ Yücel, agm, s. 840.

${ }^{56}$ Akın, agm, s. 915.

57 “Kars’ta DP Adaylarını Takdim Ediyoruz,” Hüryurt Gazetesi, 9 Ekim 1957.
} 
1957 genel seçimlerinde Kars'taki seçmen sayısı 192.569'dur. Partilere verilen oylar hesap edildiğinde ortalama 40.000 'e yakın seçmenin oy kullanmadığ görülmektedir. $^{58} 1957$ seçim sonuçlarına göre Kars'ta CHP 90.368 oy, DP 56.742 oy, CMP 1.161 oy ve HP 6.068 oy ald. Bu sonuçlara göre CHP Kars'tan tek liste olarak kazandı ve bütün adaylarını meclise sokmayı başard1. ${ }^{59} \mathrm{Bu}$ seçimlerde CHP'nin adayları ortalama 90.000 ve üzerinde oy alırken, Abbas Çetin 57.136, Latif Aküzüm 57.108 ve Veyis Koçulu 57.052 oy alabildiler ve DP döneminin son milletvekili seçiminde de meclise girmeyi başaramadılar. ${ }^{60}$

\section{Abbas Çetin}

DP'ye geçen üç milletvekilinden birisi olan Abbas Çetin 1914 (1330) Revan doğumludur. Birinci Cihan Savaşı'ndan sonra anavatana iltica ederek Kars'a yerleşmiştir. İlk tahsilini Kars'ta, orta ve liseyi Erzurum Erkek Lisesi'nde bitirdikten sonra 1937-1938 ders yılında Ankara Hukuk Fakültesi'nden mezun oldu. Aynı sene yedek subay okuluna girdi. Topçu asteğmen olarak okuldan çıkan Çetin, Sarıkamış 9. Topçu Alayında ve İzmir müstakil koşulu taburda hizmet ederek 15 Aralık 1939'da üsteğmen rütbesiyle terhis edildi. Mesleki stajını Kars'ta yaptıktan sonra 9 Mayıs 1940'da Yıldızeli Hâkim Yardımcılığı, Kars'ın Kağızman ilçesinde, Kars merkezinde, Malatya'nın Pütürge ilçesinde, Erzincan ve Yozgat merkezlerinde yargıçlık ve savcılık yaptı. 1949'da görevinden istifa ederek Kars'ta avukatlık yapmaya başladı. 14 Mayıs 1950 seçimlerinde Kars'ta 74.250 oy alarak 9.dönem milletvekili seçildi. ${ }^{61}$ 18 Mart 1952'de CHP'den istifa ederek DP saflarına geçen Abbas Çetin; Ekonomi, Meclis Hesaplarını İnceleme ve Adalet komisyonlarında çalıştı. Orman Kanunu Tasarısı için kurulan geçici komisyonda görev alan ${ }^{62}$ Çetin 9. Dönem TBMM'de 33 farklı konuda söz alarak genel kurula hitabetti. $^{63}$

\section{Veyis Koçulu}

CHP'den 1950 yılında milletvekili seçildikten sonra DP'ye geçen bir diğer milletvekili Veyis Koçulu; 1891 Tiflis’te doğumludur ve Ardahan'ın Göle İlçesi Küçükboğatepe Köyü'nde nüfusa kayıtlıdır. 1921 senesinde ailesiyle birlikte anavatana iltica edip Kars'a yerleşen Koçulu, hayvan yetiştiriciliği, sütçülük ve peynircilikle uğraşmaktaydı. 1929 senesinde CHP Kars teşkilatına katıldı. 1929'dan sonra yedi sene Çakmak Bucak Parti Başkanlığına, 4 senede CHP il idare kurulu üyeliğine ve 6., 7. ve 8. devrelerde Kars İl Genel Meclis Üyeliğine seçilerek vazifelerde bulundu. 14 Mayıs 1950 seçimlerinde 70.847 oy alarak 9. Dönem Kars CHP Milletvekili seçildi. Seçim tutanağını 17 Mayıs'ta 1950'de alarak 22 Mayıs 1950'de meclise girdi. $^{64}$ 9. Dönemde Bayındırlık Vekaleti, Karayolları Genel Müdürlüğ 1953 yılı bütçesi ve Tarım Bakanlı̆̆ı, Devlet Üretme Çiftlikleri Genel Müdürlüğü ile Orman Genel Müdürlüğü 1952 yılı bütçesi münasebetiyle iki defa söz aldı. ${ }^{65}$

\section{Latif Aküzüm}

1950 seçimlerinde CHP'den seçime giren ve daha sonra DP'ye geçen üçüncü milletvekili olan Latif Aküzüm, 1912 (1328) yılında Kars'ın Arpaçay ilçesinin Aküzüm Köyü'nde doğdu. İlk ve orta tahsilini Kars’ta, lise tahsilini Bursa ve İstanbul Lisesi'nde yapan Aküzüm, Ankara

\footnotetext{
58 “Vilayetimiz Seçiminde DP ve CHP Adaylarının Aldıkları Oylar,” Birlik Gazetesi, 2 Kasım 1957.

${ }^{59}$ DİGM, age, s. 28-29.

${ }^{60}$ Birlik Gazetesi, 2 Kasım 1957, agh.

${ }^{61}$ TBMM Arşivi, Abbas Çetin, Özlük Dosyası, Sicil No: 1735, Dönem 9.

${ }^{62}$ Olcay Hangül, Olcay, 1950-1960 TBMM’deki Kars Milletvekilleri ve Faaliyetleri, (Yayınlanmamış Yüksek Lisans Tezi), Kars, 2013, s. 23.

${ }^{63} \mathrm{http} / / /$ www.tbmm.gov.tr/develop/owa/tutanak_erisim.Uyeler, (E.T. 30.08.2018).

${ }^{64}$ TBMM Arşivi Veyis Koçulu Özlük Dosyası, Sícil No: 1736, Dönem 9.

${ }^{65} \mathrm{http}: / /$ www.tbmm.gov.tr/develop/owa/tutanak_erisim.Uyeler, (E.T. 30.08.2018).
} 
Hukuk Fakültesi'nden mezun oldu. ${ }^{66} 1935$ 'de İstatistik Umum Müdürlüğü'nde çalıştı. ${ }^{67} 30$ Kasım 1940’ta iktisat Bakanlığı Zonguldak Mıntıka Müdürlüğ̈ memur adaylığına atandı fakat avukatlık mesleğini yerine getirmek için memurluk görevinden istifa ederek ayrıldı ve Kars'ta serbest avukatlık yapmaya başladı. ${ }^{68}$ İktisat Vekaleti Umum Müdürlüğü memurluğu da yaptı. ${ }^{69}$

14 Mayıs 1950 seçimlerinde 76.064 oy alarak 9. Dönemde Kars Milletvekilliğine seçildi. ${ }^{70}$ Seçim tutanağını 17 Mayıs 1950'de alarak 22 Mayıs 1950 tarihinde Meclise girdi. DP'ye geçtikten sonra Adalet Komisyonu'nda çalışan Aküzüm, orman kanunu, kan gütme, Orman Genel Müdürlüğü Teşkilâtı, memur ve subayların karşılama ve uğurlamada bulunamayacağg ve amme malları konularında kurulan geçici komisyonlar ile geçici Dilekçe ve Adalet komisyonlarında görev aldı. ${ }^{71}$ İkisi Horasan-Kızılçakçak yolu ile Kars-Digor şosesi konularında olmak üzere $15 \mathrm{kez}$ mecliste söz aldı. ${ }^{72}$

2 Ekim 1952 tarihinde Kars Orduevinde Cumhurbaşkanının şerefine verilen ziyafetten gece çıkarken aynı semtte oturanlarla birlikte bir gurup halinde evlerine dönmekte iken kendisini dövdüğü ve tahkir ettiği Kars Gazetesi sahibi Fuat Araslı tarafindan şikayet olunan Latif Aküzüm hakkında Kars Cumhuriyet Müddeiumumiliğinden 22.04.1953 tarihli ve 561 sayılı başvekalete gönderilen yazıda Türk Ceza Kanununun 456/4 ve 482. Maddelerine tevfikan takibat icrası için dokunulmazlığının kaldırılması istendi. ${ }^{73}$

\section{Sonuç}

7 Ocak 1946 tarihinde CHP'den ayrılan dört milletvekili, Adnan Menderes, Fuat Köprülü, Refik Koraltan ve Celal Bayar'ın önderliğinde Demokrat Parti kuruldu. Kuruluşunun ardından yapılan ilk milletvekili seçimlerinde teşkilatlanmasını tamamlayamadığı için birçok ilde seçime giremeyen DP, yine de meclise 66 milletvekili sokmayı başardı. Tarihe "hileli seçimler" olarak geçen bu seçimlerin ardından CHP ve DP arasında gerginlikler yaşansa da CHP ve DP'nin üzerinde anlaştığı seçim yasasındaki değişikliklerin ardından 14 Mayıs 1950'de yeniden seçime gidildi.

14 Mayıs'ta yapılan seçimler Türk siyaset tarihinde önemli bir dönüm noktası oldu. 27 yıllık CHP iktidarı artık sona erdi ve 27 Mayıs darbesine kadar devam edecek olan DP dönemi başladı. 1950-1960 yılları arası yapılan üç milletvekili seçiminde de DP ülke çapında önemli başarılar gösterse de Kars'tan milletvekili çıkarmayı başaramadı. Fakat 1950 seçimlerinde sonra Kars'ta istisnai bir durum yaşand. CHP listesinden seçimi kazanarak meclise giren üç vekil, Abbas Çetin, Veyis Koçulu ve Latif Aküzüm, partilerinden istifa ederek DP saflarına geçtiler. İstifa gerekçelerinde: CHP'de halen şef sisteminin devam ettiğini, namuslu ve dürüst vatandaşların fişlere raptedilip süründürüldüklerini, zümreci ve parçalayıcı zihniyetin Halk Partisinde benimsendiğini ve Kars il kongresinde usulsüzlüklerin yapıldığını ifade eden istifa mektubu yazdılar. Bu mektubun yayınlanmasının ardından dönemin gazetelerinde istifa eden vekiller ile CHP'li siyasetçiler arasında basın üzerinden söz düelloları yaşandı. Bu düellolar özellikle DP'ye yakınlığı ile bilinen Zafer Gazetesiyle CHP çizgisinde yayınlar yapan Ulus Gazetesi üzerinden yapılmaktayd.

\footnotetext{
${ }^{66}$ TBMM Arşivi Latif Aküzüm Özlük Dosyası, Sicil No: 1733, Dönem 9.

${ }^{67}$ BCA, 490.01.306.1242.1.69.

${ }^{68}$ BCA, 490.01.306.1242.1.66.

${ }^{69}$ Türkiye Büyük Millet Meclisi Albümü, 1920- 2010, 2. Cilt, 1950-1980, TBMM Basın ve Halkla İlişkiler

Müdürlüğü Yayınları, Gökçe Ofset Matbaacılık, Yayın No: 1, 2010, s. 572.

70 TBMM Arşivi Latif Aküzüm, agb.

${ }^{71}$ Hangül, agt, s. 43.

72 http://www.tbmm.gov.tr/develop/owa/tutanak erisim.Uyeler, (E.T. 30.08.2018).

${ }_{73}$ BCA, 030.10.9.53.15.
} 
CHP'den istifa eden üç vekil, 1954 ve 1957 yılında yapılan milletvekili seçimlerinde Kars'ta DP listesinden aday oldular. Kars'taki kötü gidişatın önüne geçebilmek için 1954 seçimlerinden önce Celal Bayar ve 1957 seçimlerinde önce de Adnan Menderes Kars'a gelip seçim çalışmalarında bulundular. Fakat sonuç değişmedi ve DP, istifa eden üç vekil dışında Kars'tan milletvekili çıkartamadı.

\section{Kaynakça:}

\section{Arşiv Belgeleri}

Başbakanlık Cumhuriyet Arşivi, 030.10.77.511.11.

BCA, 030.10.78.517.15.

BCA, 030.10.9.53.15.

BCA, 490.01.306.1242.1.66.

BCA, 490.01.306.1242.1.69.

\section{Resmi Belgeler}

Devlet İstatistik Genel Müdürlüğ̈̈, 1950-65 Milletvekili ve 1961-64 Cumhuriyet Senatosu Üye Seçim Sonuçları, No: 513, Ankara, 1966.

DİGM, 1951 İstatistik Ylllı̆gl, Yayın No: 332, Ankara, 1951.

DİGM, Milletvekilleri Genel Seçimleri 1923-2007, TÜİK Matbaası, Ankara, 2008.

DİGM, Milletvekilleri Genel Seçimleri 1923-2007, Ankara, 2008.

“Cemiyetler Kanunun Bazı Maddelerinin Değiştirilmesine Dair Kanun," Resmi Gazete, 10 Haziran 1946.

Türkiye İstatistik Kurumu, Milletvekili Genel Seçimleri 1923-2011, Yayın No: 3685, Ankara, 2012.

Türkiye Büyük Millet Meclisi Albümü, 1920- 2010, 2. Cilt, 1950-1980, TBMM Basın ve Halkla İlişkiler Müdürlüğü Yayınları, Gökçe Ofset Matbaacılık, Yayın No: 1, 2010.

Türkiye Büyük Millet Meclisi Arşivi, Abbas Çetin, Özlük Dosyası, Sicil No: 1735, Dönem 9.

TBMM Arşivi, Latif Aküzüm Tercüme-i Hal Kağıdı, Sicil No: 1733, Dönem 9.

TBMM Arşivi, Veyis Koçulu Tercüme-i Hal Kağıdı, Sicil No: 1736, Dönem 9.

TBMM, Tutanak Dergisi, 16.02.1950.

TBMM, Tutanak Dergisi, 29.05.1950

\section{Gazeteler}

“Üç Kars Milletvekili CHP'den İstifa İle DP’ye Geçtiler,” Akşam Gazetesi, 19 Mart 1952.

“Üç Kars Milletvekili CHP'den İstifa Etti” Milliyet Gazetesi, 19 Mart 1952.

“CHP’den İstifa Eden Üç Kars Milletvekili Dün İthamlara Cevap Verdiler,” Milliyet Gazetesi, 21 Mart 1952

"Halk Partisinde Yeni Çöküntüler," Zafer Gazetesi, 19 Mart 1952.

History Studies 
“Halk Partisi Çöküyor,” Zafer Gazetesi, 19 Mart 1952.

“CHP'deki Bozgunun Sebepleri,” Zafer Gazetesi, 21 Mart 1952.

“CHP Tarafindan Gösterilen Adaylar," Kars Gazetesi, 26 Nisan 1950.

“L. Aküzüm, A. Çetin ve V. Koçulu CHP'den DP'ye Geçtiler," Kars Gazetesi, 19 Mart 1952.

“Üç Vekilimizin İstifaları, Türk Matbuatı Ne Diyor,” Kars Gazetesi, 24 Mart 1952.

"Üç Vekilimizin İstifaları Hakkında Hemşerilerimizin Anketimize Verdikleri Cevaplar," Kars Gazetesi, 25-26-27-28-29 Mart 1952.

“Milletvekillerimiz Arasında Düello,” Kars Gazetesi, 27 Mart 1952.

“Milletvekillerimiz Arasında Düello," Kars Gazetesi, 28 Mart 1952.

“Milletvekillerimiz Arasında Yazı Düellosu Devam Ediyor,” Kars Gazetesi, 29 Mart 1952.

"Milletvekillerimiz Arasında Yazı Düellosu Devam Ediyor," Kars Gazetesi, 30 Mart 1952.

"Yetkili Parti Müfettişleri İl İdare Kuruluna Kifayetsizlikten Dolayı İşten El Çektirdi," Kars Gazetesi, 19 Ağustos 1952.

“Seçimler Tamamen Vukuatsız Geçmiştir," Kars Gazetesi, 3 Mayıs 1954.

“Kars’ta DP Adaylarını Takdim Ediyoruz,” Hüryurt Gazetesi, 9 Ekim 1957.

"Vilayetimiz Seçiminde DP ve CHP Adaylarının Aldıkları Oylar," Birlik Gazetesi, 2 Kasim 1957.

\section{Kitap ve Makaleler}

AKIN, Rıdvan, "Türkiye'de Çok Partili Siyasi Hayat Geçiş ve Demokrat Parti Yılları (1945-1960)," Türkler, 16. Cilt, Yeni Türkiye Yayınları, Ankara, 2002, s. 911-922.

AYDEMİR, Şevket Süreyya, Menderes 'in Dramı, 14. Basım, İstanbul, Şubat 2013.

BAKAN, Selahaddin - ÖZDEMIR Hakan, “Türkiye'de 1946-1960 Dönemi İktidarMuhalefet İlişkileri: Cumhuriyet Halk Partisi Demokrat Parti'ye Karşı," $C \ddot{U}$, İktisadi ve İdari Bilimler Fakültesi Dergisi, Cilt 14, Sayı: 1, 2013, s. 373-397.

BULUT, Sedef, "27 Mayıs 1960'dan Günümüze Paylaşılamayan Demokrat Parti Mirası," SDÜ Fen Edebiyat Fakültesi, Sosyal Bilimler Dergisi, Mayıs 2009, Sayı 19, s. 7390.

BURÇAK, Rıfkı Salim, On Yılın Anıları (1950-1960), Ankara, Nurol Matbaacılık, 1998.

ÇAVDAR, Tevfik, Türkiye'nin Demokrasi Tarihi 1839-1950, Ankara, İmge Kitapevi Yayınları, 1995.

ÇOLAK, Filiz, "Türkiye'de Çok Partili Hayata Geçiş ve Demokrat Parti (1945-1950)," Türkler, 16. Cilt, Yeni Türkiye Yayınları, Ankara, 2002, s. 774-782.

DUMAN, Olcay Ö. - BİRSEL Haktan, "Demokrat Parti'nin Dış Politikası ve Bu Politikanın Dinamiklerine Etki Eden Dış Gelişmeler," Atatürk Üniversitesi, Atatürk IIlkeleri ve İnkilap Tarihi Enstitüsü, Atatürk Dergisi, 2012, s. 299-318.

FERSOY, Orhan Cemal, Bir Devre Adını Veren Başbakan Adnan Menderes, İstanbul, Maytaş Matbaacılık, 1971. 
GÜNGÖR, Süleyman “14 Mayıs 1950 Seçimleri ve CHP'de Bunalım,” SDÜ Fen Edebiyat Fakültesi Sosyal Bilimler Dergisi, Say1 21, Mayıs 2010, s. 193-208.

HAYTOĞLU, Ercan, “1945'te Çok Partili Siyasi Hayata Geçişte Bir İlk: Milli Kalkınma Partisi," Türkler, Yeni Türkiye Yayınları, Ankara, 2002, s. 783-797.

KÜRKÇÜOĞLU, Ömer, "Dış Politika nedir? Türkiye'nin Dünü ve Bugünü,” $A \ddot{U} S B F$ Dergisi, Cilt 35, Say1:1, 1980, s. 309-335.

ÖZDEMİR, Hikmet "Demokrasiye Geçiş ve Menderes Dönemi," Türkler, Cilt 16, Yeni Türkiye Yayınları, Ankara, 2002, s. 878-900.

ÖZGÜL, Bülent, Seçim ve Seçim Sistemleri, Türkiye'deki Seçim Sistemi Uygulamaları ve Bir Model Önerisi, (Süleyman Demirel Üniversitesi, Yayımlanmamış Yüksek Lisans Tezi), Isparta, 2002.

TOPÇU, İlyas - ARSLAN, O. Nebahat, "Kars’ta 1950-1954-1957 Milletvekili Seçimleri ve Demokrat Parti", Türkiyat Araştırmaları Enstitüsü Dergisi, Sayı: 58, 2017, s. 389-407.

TURP, Muharrem, “Türkiye'nin Demokratikleşme Sürecinde Bir Mihenk Taşı: Basında 1950 Seçimleri," Çağdaş Türkiye Tarihi Araştırmaları Dergisi, 18/37, 2018, s. 677-714.

YÜCEL, M. Serhan, “Menderes Dönemi (1950-1960),” Türkler, Yeni Türkiye Yayınları, Ankara, 2002, s. 835-854.

ZÜRCHER, J. Erik, Modernleşen Türkiye'nin Tarihi, Çev: Yasemin S. Gönen, İletişim Yayınları, İstanbul, 1995.

\section{Tezler}

ATAYKUL, Fatma Alev, Türkiye'de Demokrat Parti Döneminde Genel Seçimler (19501954-1957), (Yayınlanmamış Yüksek Lisans Tezi), İstanbul, 2007.

HANGÜL, Olcay, 1950-1960 TBMM'deki Kars Milletvekilleri ve Faaliyetleri, (Yayınlanmamış Yüksek Lisans Tezi), Kars, 2013.

İNAN, Süleyman, Muhalefette Adnan Menderes (1945-1950), (Yayınlanmamış Doktora Tezi), Isparta, 2002.

\section{Internet Sayfasi}

http://www.tbmm.gov.tr/develop/owa/tutanak erisim.Uyeler, (E.T. 30.08.2018). 